\title{
Enteropathy-associated T-cell lymphoma (type II): a Brazilian case report
}

\author{
Aloísio Felipe-Silva ${ }^{a}$, Fernando Peixoto Ferraz de Campos ${ }^{b}$, \\ Raphael Salles Scortegagna de Medeiros ${ }^{c}$, Rodrigo Montenegro Lourenção ${ }^{d}$, \\ Maria Claudia Nogueira Zerbini ${ }^{a, e}$
}

Felipe-Silva A, Campos FPF, Medeiros RSS, Lourenção RM, Zerbini MCN. Enteropathy-associated T-cell lymphoma (type II): a Brazilian case report. Autopsy Case Rep [Internet]. 2012;2(2):31-36. http://dx.doi.org/10.4322/acr.2012.014

\section{ABSTRACT}

\begin{abstract}
Enteropathy-associated T-cell Lymphoma (EATL) is a rare form of aggressive T-cell lymphoma. It is more prevalent in men over 60 years and the prognosis is very poor. EATL is classified into two groups based on morphology, immunohistochemistry, and genetic profile. EATL type I is highly associated with celiac disease and is more common in Western countries. EATL type II predominates over type I in Asia, where celiac disease is uncommon. We report a case of a 78-year-old previously healthy white male who presented with a 2-month history of diarrhea, weight lossand edema. Theabdomen was distended and painful, and a tumor mass was palpable in the hypogastrium. Laboratory tests showed hypoalbuminemia. Serological tests for HIV, viral hepatitis and HTLV-1 were negative. The chest radiography showed pneumoperitoneum, and an exploratory laparotomy revealed perforation of the small bowel. An advanced stage (Ann Arbor IV B/Lugano IIE2B) EATL type II was diagnosed. Four cycles of chemotherapy were interspersed with several complications (anthracycline-induced cardiotoxicity, chemotherapy-induced neutropenic fever and severe sepsis). Performance status progressively worsened and he died 6 months after the diagnosis. This is an illustrative report of a rare and aggressive primary intestinal lymphoma. To the best of our knowledge, this is the first report of EATL type II in Brazil.
\end{abstract}

Keywords: Enteropathy-Associated T-Cell Lymphoma; Celiac Disease; Lymphoma, Non-Hodgkin; Intestinal Perforation; Lymphoma, T-Cell.

\section{CASE REPORT}

A 78-year-old previously healthy white male patient sought medical care with a 2-month history of diarrhea accompanied by $20 \mathrm{~kg}$ of weight loss. He denied fever or night sweats. One month prior the hospital admission a slight lower-limb edema started, which progressively worsened reaching the thighs. An erythematic eruption also appeared on the anterior surface of both legs. On

\footnotetext{
a Anatomic Pathology Service - Hospital Universitário - Universidade de São Paulo, São Paulo/SP - Brazil.

${ }^{\text {b } D e p a r t m e n t ~ o f ~ I n t e r n a l ~ M e d i c i n e ~-~ H o s p i t a l ~ U n i v e r s i t a ́ r i o ~-~ U n i v e r s i d a d e ~ d e ~ S a ̃ o ~ P a u l o, ~ S a ̃ o ~ P a u l o / S P ~-~ B r a z i l . ~}$

c Instituto do Câncer do Estado de São Paulo, São Paulo/SP - Brazil.

${ }^{\mathrm{d}}$ Department of Surgery - Hospital Universitário - Universidade de São Paulo, São Paulo/SP - Brazil.

e Department of Pathology - Faculdade de Medicina - Universidade de São Paulo, São Paulo/SP - Brazil.
} 
the day of hospital admission he referred an intense and diffuse abdominal pain radiating to the back.

The physical examination revealed an illlooking, pale, and dehydrated patient. The pulse rate was 120 beats per minute and blood pressure was $90 / 50 \mathrm{mmHg}$. The lower limbs were edematous, with bullous lesions over an erythematous skin (consistent with erysipela) on the anterior surface of both legs. The heart and lungs examination was unremarkable. The abdomen was distended, painful, and a tumor mass was palpable in the hypogastrium. Bowel sounds were absent and the rebound tenderness (Bloomberg sign) was positive.

Laboratory tests are shown in Table 1. Serological tests for HIV, hepatitis (B and $C$ ) and HTLV-1 were negative.

The chest radiography showed the image of pneumoperitoneum. The patient underwent an exploratory laparotomy, which revealed a large amount of enteric fluid in the abdominal cavity and perforation of the small intestine at $15 \mathrm{~cm}$ and $220 \mathrm{~cm}$ from the Treitz angle. The two perforated segments were resected. The post-operative follow up was marked by generalized edema and hypoalbuminemia.

Gross examination of enterectomy specimens revealed two segments of jejunum (42 $\mathrm{cm}$ length each). Each segment presented a
$5.5 \mathrm{~cm}$ ulcerated, infiltrated, whitish and soft tumor (Figure 1). Tumor perforation was detected in one segment as well as suppurative serositis. Whitish and soft enlarged lymph nodes (up to $3.0 \mathrm{~cm}$ ) adhered to the segment. Surrounding mucosa and bowel wall were somewhat thickened and rubbery.

On microscopic examination, tumor masses invaded through the wall of the intestine (Figure 2A) and were composed by cells with medium-sized round or irregular, darkly staining nuclei with a rim of pale or eosinophilic cytoplasm (Figure 2B). Frequent mitotic figures and some enlarged nucleoli were seen. Intestinal crypts and surface epithelium were diffusely infiltrated by malignant cells. Villous atrophy and crypt hyperplasia were also present (Figure 2C and 2D). Two adjacent lymph nodes were invaded by tumor cells. No other foci of infiltration were detected.

On immunohistochemistry analysis, neoplastic cells were CD3+, CD8+ and CD56+, which was consistent with a natural killer like (NK-like) $\mathrm{T}$ cell or even NK phenotype (Figure 3A and C). Immunostaining for CD20, CD30, ALK, CD4 and $\mathrm{CD} 5$ were all negative. Proliferation index by Ki67 was $60-70 \%$. Pancytokeratin immunostaining with $A E 1+A E 3$ highlighted villous atrophy and intraepithelial infiltration by both individual and clusters of tumor cells (Figure 3D). These findings were consistent with enteropathy-associated T-cell lymphoma type II (EATL type II).

Table 1 - Laboratory work up

\begin{tabular}{cccccc}
\hline Exam & Result & RV & Exam & Result & RV \\
\hline Hemoglobin & 13.2 & $12.3-15.3 \mathrm{~g} / \mathrm{dL}$ & Creatinine & 1.4 & $0.4-1.3 \mathrm{mg} / \mathrm{dL}$ \\
Hematocrit & 40 & $36.0-45.0 \%$ & Urea & 57 & $10-50 \mathrm{mg} / \mathrm{dL}$ \\
Leukocytes & 9.1 & $4.4-11.3 \times 10^{3} / \mathrm{mm}^{3}$ & lonized Ca+ & 1.07 & $1.15-1.35 \mathrm{Mmol} / \mathrm{L}$ \\
Promyelocytes & 1 & 0 & Sodium & 138 & $136-146 \mathrm{mEq} / \mathrm{L}$ \\
Myelocytes & 3 & 0 & Potassium & 5.3 & $3.5-5.0 \mathrm{mEq} / \mathrm{L}$ \\
Metamyelocytes & 5 & AST & 20 & $10-31 \mathrm{IU} / \mathrm{L}$ \\
Bands & 25 & $1-5 \%$ & ALT & 21 & $9-36 \mathrm{IU} / \mathrm{L}$ \\
Segmented & 50 & $46-75 \%$ & Alkaline phosphatase & 83 & $10-100 \mathrm{IU} / \mathrm{L}$ \\
Eosinophils & 0 & $1-4 \%$ & rGT & 46 & $2-30 \mathrm{IU} / \mathrm{L}$ \\
Basophils & 0 & $0-2.5 \%$ & Total bilirubin & 0.7 & $0.3-1.2 \mathrm{mg} / \mathrm{dL}$ \\
Lymphocytes & 15 & $18-40 \%$ & Total protein & 3.7 & $6.0-8.0 \mathrm{~g} / \mathrm{dL}$ \\
Monocytes & 1 & Albumin & 1.0 & $3.0-5.0 \mathrm{~g} / \mathrm{dL}$
\end{tabular}

$\mathrm{ALT}=$ alanine aminotransferase, $\mathrm{AST}=$ aspartate aminotransferase, $\gamma \mathrm{GT}=$ gamma-glutamyl transferase, $\mathrm{LDH}=$ serum lactate dehydrogenase, $\mathrm{RV}=$ reference value. 


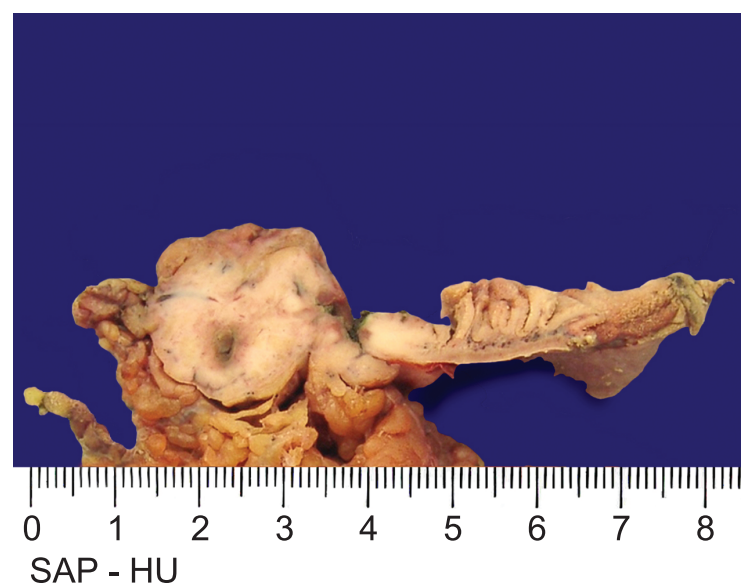

Figure 1 - View of a section through small bowel EATL type II.

Post-operative abdominal computed tomography (CT) revealed the presence of confluent lymph nodes, near the superior mesenteric vascular bundle, measuring up to $2.5 \mathrm{~cm}$ with homogeneous enhancement by the contrast medium. Neck and chest CT did not detect lymphadenopathy.

The patient developed nosocomial pneumonia, which delayed the start of the specific treatment. After clinical improvement he was referred to an oncology center. Bone marrow biopsy revealed no lymphoma infiltration. Disease was staged Ann Arbor IV B/Lugano IIE2B. Treatment started with $\mathrm{CHOP}$ chemotherapy and was changed to COP scheme after 2 cycles. The patient developed anthracycline-induced cardiotoxicity, chemotherapy-induced neutropenic fever and severe sepsis. Performance status progressively worsened and he died 6 months after the diagnosis. Postmortem examination was not requested.

\section{DISCUSSION}

The gastrointestinal tract is the most common location of extranodal lymphomas. The stomach is the most frequent site of involvement (mainly due to Helicobacter pylori associated mucosal associated lymphoid tissue - MALT - lymphoma), followed by the small intestine. ${ }^{1,2}$ Primary large bowel and rectum lymphomas are much less common. ${ }^{3}$

Most gastrointestinal primary lymphomas are of B phenotype (MALT lymphoma, large B cell lymphoma, mantle cell lymphoma, follicular lymphoma, Burkittlymphoma and immunoproliferative small intestinal disease- IPSID). ${ }^{4}$

Primary gastrointestinal tract T-cell lymphomasaremostlyassociated withmalabsorption, as a complication of celiac sprue. These cases have been designated as "enteropathy-associated T-cell lymphoma" (EATL) and they are characterized by prominent intraepithelial lymphomatous spread and villous atrophy of uninvolved mucosa. T cells show varying degrees of transformation, frequently with an inflammatory background. $5,6,7$

EATL is considered a rare form of aggressive T-cell lymphoma accounting for less than $1 \%$ of non-Hodgkin lymphomas. The estimated annual incidence rate is $0.5-1$ per million people in Western countries. It is more prevalent in men over 60 years. ${ }^{8,9}$ The outcome is very poor with an overall survival rate of $15-20 \%$ in 2 -year. ${ }^{10}$

Based on morphology, immunohistochemistry and genetic profile EATL can be divided into two groups. EATL type I is a large-size cell lymphoma which is highly associated with celiac disease and mostly, presents with malabsorption, weight loss and celiac disease-related symptoms. Geographic distribution follows that of celiac disease, with a high prevalence in Northern Europe. Most patients show adult onset celiac disease, sometimes with an initial period of refractory disease and ulcerative jejunitis. Tumor cells are typically CD3+, CD5-, CD7+, CD8+/-, CD4-, CD30+ and contain cytotoxic granule associated proteins by immunohistochemistry. ${ }^{7,11}$

EATL type II comprises about $10-20 \%$ of EATL and is composed of monomorphic, small to medium-sized cells. Obstruction or perforation of the small bowel is common. EATL type II is not associated with celiac disease and may occur sporadically. The immunophenotype is somewhat different from EATL type I (CD3+, CD4-, CD8+, CD56+) ${ }^{5,12,13}$ Prognosis of EATL type II seems to be even worse, with median overall survival of 7 months and progression-free-survival of 1 month. ${ }^{14}$

Other T-cell lymphomas may also develop in the intestine and sometimes simulate the histologic pattern of EATL. ${ }^{15} \mathrm{~T}$-cell lymphomas can involve any part of the gastrointestinal tract, especially in patients in the Far East, where most cases are peripheral T-cell lymphomas, not otherwise specified (NOS), 


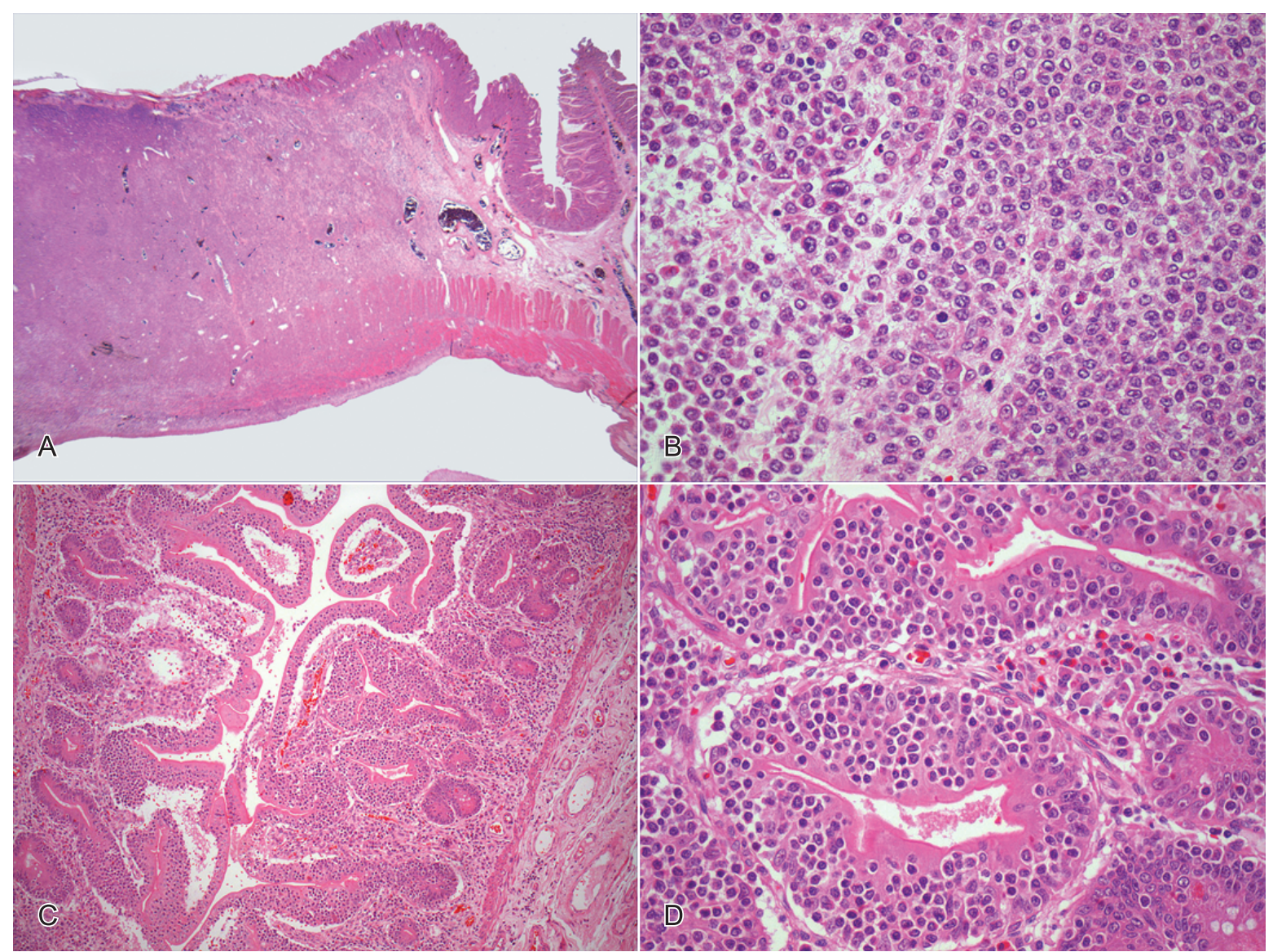

Figure 2 - Photomicrography - small bowel surgical pathology specimen. A - (H\&E, 12.5x) Tumor cells invade through the entire bowel wall. Serosal exudate secondary to perforation can be seen at the bottom; B - (H\&E, 400x) Lymphoma cells with medium-sized round or irregular, darkly staining nuclei with a rim of pale or eosinophilic cytoplasm; C - (H\&E, 100x) Villous atrophy and crypt hyperplasia; D - (H\&E, 400x) Marked intraepithelial infiltration by lymphoma cells.

NK/T-cell lymphomas of nasal type, and cases linked with the HTLV-1 virus. ${ }^{16-21}$

NK-cell enteropathy has recently been described as an entity that mimics EATL, especially the type II. In the case series reported by Mansoor et al., 8 patients presented with vague gastrointestinal symptoms and a mucosal infiltrate of atypical cells with an NK-cell phenotype. No patient developed progressive disease or died of lymphoma. In contrast with EATL type II, NK-cell enteropathy cells are CD8- and do not show marked epitheliotropism. Furthermore, clonal T-cell gene rearrangement is absent in NK-cell enteropathy. ${ }^{22}$

Differentialdiagnosis couldalsoincludeIPSID, which is an uncommon type of gastrointestinal B cell lymphoma that tends to manifest as malabsorption, presents in the duodenum or proximal jejunum, and exhibits villous atrophy as well as plasma cell infiltration of the adjacent intestine. ${ }^{23}$ Formerly known as Mediterranean lymphoma or a heavy chain disease, it mainly occurs in the Middle East and arises in association with a morphologically benign-appearing infiltrate, often characterized by a dense, plasma cell proliferation in the intestinal mucosa. ${ }^{24}$

This patient did not have a history of celiac disease. Actually, this was a quite recent onset with a clinical history of 2 months, which is consistent with EATL type II. Despite that, the patient presented with severe diarrhea and malabsorption, hypoalbuminemia and peripheral edema. In a recent large multicenter analysis of 38 patients with EATL type II, diarrhea and hypoalbuminemia were present in $21 \%$ and $90 \%$ of the cases, respectively. ${ }^{14}$

In summary, this is an illustrative report of a rare and aggressive primary intestinal lymphoma. To the best of our knowledge, this is the first report of EATL type II in Brazil. 


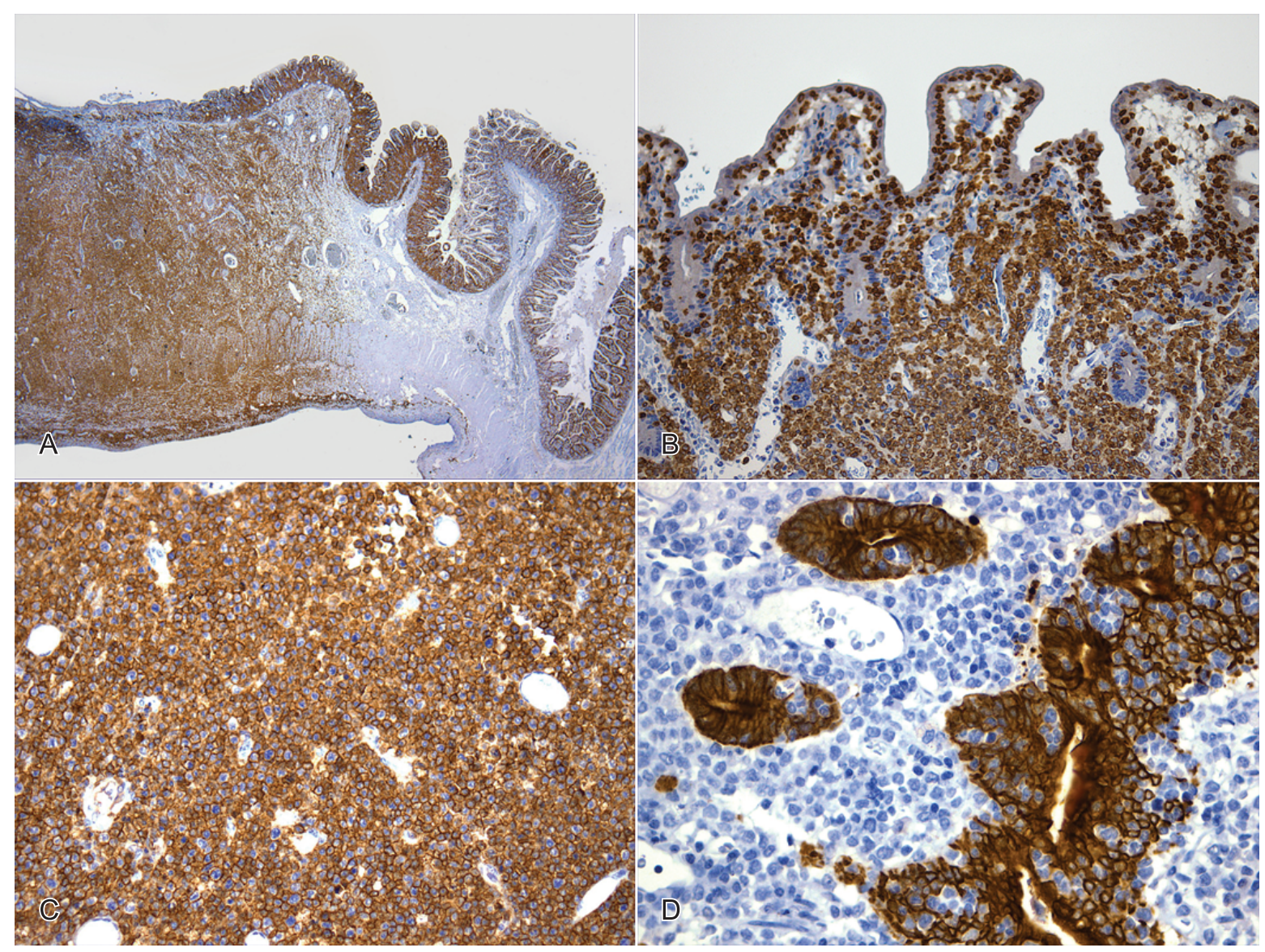

Figure 3 - Phootomicrography - Immunohistochemistry. A - (CD3, 12.5x) CD3+ T-cells invade through the entire bowel wall; B - (CD3, 200x) Striking intraepithelial infiltration by CD3+ lymphoma cells; C - (CD56, 200x) CD56+ cells featuring EATL type II; D - (AE1+AE3, 400x) Pan-cytokeratin stains intestinal epithelium, highlighting clusters of intraepithelial lymphoid cells.

\section{REFERENCES}

1. Groves FD, Linet MS, Travis LB, Devesa SS. Cancer surveillance series: non-Hodgkin's lymphoma incidence by histologic subtype in the United States from 1978 through 1995. J Natl Cancer Inst. 2000;92(15):1240-51. http://dx.doi.org/10.1093/jnci/92.15.1240

2. Koch P, Del Valle F, Berdel WE, et al. Primary gastrointestinal non-Hodgkin's Iymphoma: I. Anatomic and histologic distribution, clinical features, and survival data of 371 patients registered in the German Multicenter Study GIT NHL 01/92. J Clin Oncol. 2001;19(18):3861-73. PMid:11559724.

3. Shepherd NA, Hall PA, Coates PJ, Levison DA. Primary malignant lymphoma of the colon and rectum. A histopathological and immunohistochemical analysis of 45 cases with clinicopathological correlations. Histopathology. 1988;12(3):235-52. PMid:3366441. http:// dx.doi.org/10.1111/j.1365-2559.1988.tb01939.x

4. Isaacson PG. Gastrointestinal Iymphoma. Hum Pathol. 1994;25(10):1020-9. http://dx.doi.org/10.1016/00468177(94)90060-4

5. Isaacson PG, Chott A, Ott G, Stein H. Enteropathy-associated T-cell lymphoma. In: Swerdlow SH, Campo E, Harris NL, et al., editors. WHO Classification of Tumours of Haematopoietic and Lymphoid Tissues. 4th ed. Lyon: International Agency of Research in Cancer; 2008. v. 2, p. 289-91.

6. Chott A, Dragosics B, Radaszkiewicz T. Peripheral T-cell lymphomas of the intestine. Am J Pathol. 1992;141(6):1361-71. PMid:1466400 PMCid:1886751.

7. Delabie J, Holte H, Vose JM, et al. Enteropathy-associated T-cell lymphoma: clinical and histological findings from the international peripheral T-cell lymphoma project. Blood. 2011;118(1):148-55. PMid:21566094. http://dx.doi. org/10.1182/blood-2011-02-335216

8. Di Sabatino A, Corazza GR. Coeliac disease. Lancet. 2009;373(9673):1480-93. http://dx.doi.org/10.1016/ S0140-6736(09)60254-3

9. Verbeek WH, Van De Water JM, Al-Toma A, Oudejans JJ, Mulder CJ, Coupé VM. Incidence of enteropathy-associated T-cell lymphoma: a nation-wide study of a population-based registry in The Netherlands. Scand J Gastroenterol. 2008;43(11):1322-8. PMid:18618372. http:// dx.doi.org/10.1080/00365520802240222

10. Al-Toma A, Verbeek WH, Hadithi M, Von Blomberg $\mathrm{BM}$, Mulder CJ. Survival in refractory coeliac disease 
and enteropathy-associated T-cell Iymphoma: retrospective evaluation of single-centre experience. Gut. 2007;56(10):1373-8. PMid:17470479 PMCid:2000250. http://dx.doi.org/10.1136/gut.2006.114512

11. Wright $\mathrm{DH}$. Enteropathy associated T cell lymphoma. Cancer Surv. 1997;30:249-61. PMid:9547996.

12. Chott A, Haedicke W, Mosberger I, et al. Most CD56+ intestinal lymphomas are CD8+CD5-T-cell lymphomas of monomorphic small to medium size histology. Am J Pathol. 1998;153(5):1483-90. http://dx.doi.org/10.1016/ S0002-9440(10)65736-7

13. Van De Water JM, Cillessen SA, Visser OJ, Verbeek WH, Meijer CJ, Mulder CJ. Enteropathy associated T-cell lymphoma and its precursor lesions. Best Pract Res Clin Gastroenterol. 2010;24(1):43-56. http://dx.doi.org/10.1016/j. bpg.2009.11.002

14. Tse E, Gill H, Loong F, et al. Type II enteropathy-associated T-cell lymphoma: A multicenter analysis from the Asia Lymphoma Study Group. Am J Hematol [Internet]. 2012 May 28; [Epub ahead of print; cited 2012 Jun 12]. Available from: http://onlinelibrary.wiley.com/doi/10.1002/ajh.23213/ pdf doi: 10.1002/ajh.23213.

15. Domizio P, Owen RA, Shepherd NA, Talbot IC, Norton AJ. Primary lymphoma of the small intestine. A clinicopathological study of 119 cases. Am J Surg Pathol. 1993;17(5):429-42. PMid:8470758. http://dx.doi.org/10.1097/00000478199305000-00001

16. Kohno S, Ohshima K, Yoneda S, Kodama T, Shirakusa T, Kikuchi M. Clinicopathological analysis of 143 primary malignant lymphomas in the small and large intestines based on the new WHO classification. Histopathology. 2003;43(2):135-43. PMid:12877728. http:// dx.doi.org/10.1046/j.1365-2559.2003.01659.x

17. Tung CL, Hsieh PP, Chang JH, Chen RS, Chen YJ, Wang JS. Intestinal T-cell and natural killer-cell lymphomas in Taiwan with special emphasis on 2 distinct cellular types: natural killer-like cytotoxic T cell and true natural killer cell.
Hum Pathol. 2008;39(7):1018-25. PMid:18482744. http:// dx.doi.org/10.1016/j.humpath.2007.11.003

18. Chuang SS, Chang ST, Chuang WY, et al. NK-cell lineage predicts poor survival in primary intestinal NK-cell and T-cell lymphomas. Am J Surg Pathol. 2009;33(8):1230-40. PMid:19561449. http://dx.doi.org/10.1097/ PAS.0b013e3181a95c63

19. Ko YH, Karnan S, Kim KM, et al. Enteropathyassociated T-cell lymphoma-a clinicopathologic and array comparative genomic hybridization study. Hum Pathol. 2010;41(9):1231-7. PMid:20399483. http://dx.doi. org/10.1016/j.humpath.2009.11.020

20. Takeshita M, Nakamura S, Kikuma K, et al. Pathological and immunohistological findings and genetic aberrations of intestinal enteropathy-associated T cell lymphoma in Japan. Histopathology. 2011;58(3):395-407. PMid:21323966. http:// dx.doi.org/10.1111/j.1365-2559.2011.03768.x

21. Sun J, Lu Z, Yang D, Chen J. Primary intestinal T-cell and NK-cell lymphomas: a clinicopathological and molecular study from China focused on type II enteropathy-associated T-cell lymphoma and primary intestinal NK-cell lymphoma. Mod Pathol. 2011;24(7):983-92. PMid:21423155. http:// dx.doi.org/10.1038/modpathol.2011.45

22. Mansoor A, Pittaluga S, Beck PL, Wilson WH, Ferry JA, Jaffe ES. NK-cell enteropathy: a benign NK-cell lymphoproliferative disease mimicking intestinal lymphoma: clinicopathologic features and follow-up in a unique case series. Blood. 2011;117(5):1447-52. PMid:20966166 PMCid:3056587. http://dx.doi.org/10.1182/blood-2010-08-302737

23. Al-Saleem $\mathrm{T}, \mathrm{Al}-$ Mondhiry $\mathrm{H}$. Immunoproliferative small intestinal disease (IPSID): a model for mature B-cell neoplasms. Blood. 2005;105(6):2274-80. PMid:15542584. http://dx.doi.org/10.1182/blood-2004-07-2755

24. Burke JS. Lymphoproliferative disorders of the gastrointestinal tract: a review and pragmatic guide to diagnosis. Arch Pathol Lab Med. 2011;135(10):1283-97. http://dx.doi.org/10.5858/ arpa.2011-0145-RA

\section{Conflict of interest: None}

Submitted on: $7^{\text {th }}$ June 2012

Accept on: $11^{\text {th }}$ June 2012

Correspondence: Serviço de Anatomia Patológica

Av. Prof. Lineu Prestes, 2565 - Cidade Universitária - São Paulo/SP - Brazil

CEP: 05508-900 - Phone: +55 (11) 3091-9384

E-mail: aloisiosilva@hu.usp.br 